\title{
The Correlation between Hepatitis C Core Antigen and Hepatitis C Virus RNA Levels with Respect to Human Immunodeficiency Virus Status, Hepatitis C Virus Genotype and Interferon-Lambda-4 Polymorphism
}

\author{
Vo Duy Thong $^{\mathrm{a}}$ Srunthron Akkarathamrongsin ${ }^{\mathrm{a}} \quad$ Anchalee Avihingsanon $^{\mathrm{b}}$ \\ Apiradee Theamboonlers $^{\mathrm{a}}$ Yong Poovorawan ${ }^{\mathrm{a}}$ Pisit Tangkijvanich ${ }^{\mathrm{C}}$ \\ ${ }^{a}$ Center of Excellence in Clinical Virology, Faculty of Medicine, Chulalongkorn University, ${ }^{\mathrm{b}} \mathrm{HIV}$ Netherlands Australia \\ Thailand Research Collaboration (HIV-NAT), ' Research Unit of Hepatitis and Liver Cancer, Department of Biochemistry, \\ Faculty of Medicine, Chulalongkorn University, Bangkok, Thailand
}

\section{Key Words}

Hepatitis C core antigen - Viral load · Hepatitis C genotype . HIV coinfection · Interferon-lambda-4 polymorphism

\begin{abstract}
Objectives: Serum hepatitis $\mathrm{C}$ virus (HCV) core antigen (HCVcAg) concentrations correlate with HCV RNA levels in HCV monoinfected patients. Data in HCV/HIV coinfected patients are still limited. We aim to compare the use of HCVcAg measurement with respect to HIV status, HCV genotypes, interferon-lambda-4 (IFNL4) polymorphism and clinical parameters. Methods: We analyzed an untreated cohort of 104 patients with HCV monoinfection and 85 patients with HCV/ HIV coinfection. Serum HCVcAg was measured by a commercial chemiluminescent microparticle immunoassay. The presence of IFNL4 polymorphism ss469415590 was identified by real-time PCR. Results: $\log _{10} \mathrm{HCV}$ cAg levels were significantly correlated with corresponding $\log _{10}$ HCV RNA levels ( $r=0.889, p<0.001)$, but not with ALT levels and liver stiffness. The correlation between HCV RNA and HCVcAg was particularly high in coinfected patients and those with high viremia. Mean $\log _{10} \mathrm{HCV}$ cAg concentration was signifi-
\end{abstract}

cantly higher in coinfected patients than in monoinfected patients. Patients harboring the $\pi / T T$ genotype of ss 469415590 had significantly higher levels of $\log _{10} \mathrm{HCV}$ cAg than those with the non-TT/TT genotype. HCVcAg levels were similar across HCV genotypes. Conclusions: HCVcAg concentrations had an excellent correlation with HCV RNA levels, particularly in HCV/HIV-coinfected individuals and might be associated with IFNL4 polymorphism. HCVcAg testing could be used as an alternative to HCV RNA assays in resource-limited settings.

(c) 2015 S. Karger AG, Basel

\section{Introduction}

Hepatitis C virus (HCV) infection is a major cause of liver fibrosis, cirrhosis and hepatocellular carcinoma, affecting up to 170 million people worldwide [1]. HCV has been classified into seven major genotypes, all of which display different patterns of geographic distribution. In Thailand, approximately $2.2 \%$ of the general population is chronically infected with $\mathrm{HCV}$, and the most common genotypes are genotype 3 (HCV-3), gen-

Prof. Pisit Tangkijvanich, MD

Department of Biochemistry, Faculty of Medicine, Chulalongkorn University Rama IV Road

Bangkok 10330 (Thailand)

E-Mail pisittkvn@yahoo.com 
otype 1 (HCV-1) and genotype 6 (HCV-6) [2]. The screening tests for $\mathrm{HCV}$ infection in clinical practice rely on the detection of anti-HCV antibodies using enzyme-linked immunosorbent assays (ELISA). However, these tests cannot differentiate between resolved HCV infection and an active viral replication. Therefore, the measurement of serum HCV RNA generally serves to confirm the diagnosis of an ongoing infection [3]. In addition, monitoring of HCV RNA is crucial for assessing the treatment response to antiviral therapy [4]. Currently, real-time polymerase chain reaction (PCR)-based quantitative determination is the diagnostic gold standard. However, this assay is limited in developing countries due to costs and the requirement for a real-time PCR machine.

Recently, a highly sensitive assay for measuring serum $\mathrm{HCV}$ core antigen (HCVcAg) concentrations using a fully automated chemiluminescent microparticle immunoassay has become commercially available [5]. A number of studies have demonstrated good correlation between HCVcAg and HCV RNA levels, particularly in HCVmonoinfected individuals [6-13]. As a result, $\mathrm{HCVcAg}$ testing is considered to be an alternative assay to conventional HCV RNA quantification with the advantages of rapidity, reproducibility and feasibility in settings with limited resources [14]. To date, data regarding the correlation between HCVcAg and HCV RNA levels in patients coinfected with HIV are still limited [15-17]. In addition, the effect of different viral genotypes, particularly HCV-6 prevalent in Southeast Asia [18], on HCVcAg levels and the correlation with HCV RNA levels remains to be established.

Genome-wide association studies have reported an association between single nucleotide polymorphisms (SNPs) adjacent to the interleukin-28B (IL-28B) gene (principally rs12979860) and treatment response in patients with chronic HCV infection [19-21]. Recently, a transiently induced region (interferon-lambda-4; IFNL4) harboring a dinucleotide variant ss 469415590 (TT or $\Delta \mathrm{G}$ ) showed strong linkage disequilibrium to rs12979860 [22]. So far, this novel ss469415590 SNP is the only functional variant identified in association with $\mathrm{HCV}$ clearance [23] and also a good predictor of treatment response to pegylated IFN and ribavirin therapy [24]. However, it is unclear whether there is an association between this SNP and HCVcAg concentrations in patients with chronic $\mathrm{HCV}$ infection. Thus, the aims of this study were to evaluate the use of $\mathrm{HCVcAg}$ measurement with respect to HIV status, HCV genotypes, ss 469415590 polymorphism and clinical parameters.

\section{Materials and Methods}

\section{Patients}

$\mathrm{HCV} / \mathrm{HIV}$ coinfected patients, who were seropositive for both anti-HCV and HCV RNA, were enrolled consecutively from the HIV Netherlands Australia Thailand Research Collaboration (HIV-NAT, Bangkok, Thailand). To compare the diagnostic role of HCVcAg between coinfected and monoinfected individuals, serum samples were obtained from patients with chronic HCV monoinfection, who were positive for both anti-HCV antibody and HCV RNA. These monoinfected patients were selected randomly from a pool of patients with chronic liver disease who were followed-up at King Chulalongkorn Memorial Hospital (Bangkok, Thailand). None of the patients enrolled in this study had hepatitis $B$ virus (HBV) infection or received any antiviral therapy for chronic HCV infection when the blood sample was obtained. Written informed consent and ethical approval by the institutional review board was obtained for all patients. All blood samples were stored at $-80^{\circ} \mathrm{C}$ until examined.

\section{HCV RNA Quantification and Genotypes}

HCV RNA quantification was performed using real-time quantitative reverse transcription PCR (Abbott Molecular Inc., Des Plaines, Ill., USA) in accordance with the manufacturer's instructions. The lower and upper detection limits of the assay were $<12 \mathrm{IU} / \mathrm{ml}$ and $100,000,000 \mathrm{IU} / \mathrm{ml}$, respectively. HCV genotypes were determined by nucleotide sequencing of the core and NS5B regions followed by phylogenetic analysis as described previously [2].

\section{HCVcAg Quantification}

Quantification of HCVcAg was performed using a fully automated CMIA according to the manufacturer's instructions (Abbott Diagnostics, Tokyo, Japan). The assay allows the quantitative determination of HCVcAg in a linear range from 3 to 20,000 $\mathrm{fmol} / \mathrm{l}$, with the possibility of 1:9 automated dilutions that extend the assay linearity to $180,000 \mathrm{fmol} / \mathrm{l}[5]$.

\section{IFNL4 Genotyping}

The presence of IFNL4 polymorphism ss469415590 was identified by reverse transcription PCR assay using TaqMan genotyping assay with MGB probes (Applied Biosystems, USA) as described previously [25]. Briefly, genomic DNA of patients with chronic HCV infection was extracted from $100 \mu$ of peripheral blood mononuclear cells using the QIAamp DNA Mini Kit (Qiagen, Germany). The reaction mixture consisted of $1 \mu \mathrm{l}$ of DNA extract, $200 \mathrm{nM}$ of each probe (ss469415590_IFNL4_ VIC: $5^{\prime}$-ATCGCAGAAGGCC-3' ${ }^{\prime}$ and ss469415590_IFNL4_ FAM: $5^{\prime}$-ATCGCAGCGGCCC-3' ${ }^{\prime}$ ), $900 \mathrm{nM}$ of each primer (ss469415590_IFNL4_F: 5'-GCCTGCTGCAGAAGCAGAGA T-3' and ss469415590_IFNL4_R: 5'-GCTCCAGCGAGCGGTA GTG-3') (Applied Biosystems), $5 \mu$ l of $2 \times$ Perfect Taq Plus Master Mix (5 PRIME, Gaithersburg, Md., USA) adjusted to $10 \mu \mathrm{l}$ of final volume by distilled water. The PCR conditions were $2 \mathrm{~min}$ at $50^{\circ} \mathrm{C}, 10 \mathrm{~min}$ at $95^{\circ} \mathrm{C}, 45 \mathrm{cycles}$ of $15 \mathrm{~s}$ at $95^{\circ} \mathrm{C}$ and $2 \mathrm{~min}$ at $60^{\circ} \mathrm{C}$. The fluorescent signal was detected at the end of each cycle. The genotype of ss 469415590 was analyzed by applying the Endpoint Genotyping method (Light Cycler 480; Roche Diagnostics, USA). For this SNP, TT and $\Delta \mathrm{G}$ are defined as major and minor alleles, respectively. 
Liver Stiffness Measurement

After fasting for at least $2 \mathrm{~h}$, liver stiffness measurement was obtained from each patient using transient elastography (FibroScan; Echosens, Paris, France) according to the manufacturer's instructions. Results were recorded in kilopascals $(\mathrm{kPa})$ as the median value of all measurements. The procedure was based on at least 10 validated measurements: the success rate (ratio between numbers of validated and total measurements) was over $60 \%$ and the interquartile range was less than $30 \%$ [26].

\section{Data Analysis}

A Mann-Whitney U test or Student's test was used to compare continuous variables, and a $\chi^{2}$ test or Fisher's exact test was used to compare categorical variables. The Spearman rank correlation was used to evaluate the relationships between variables. All data were analyzed by using SPSS Statistic Software Package for Windows version 20.0 (SPSS, Chicago, Ill., USA).

\section{Results}

\section{Patient Characteristics}

A total of 189 patients with chronic HCV infection were included in this study. There were 104 patients with HCV monoinfection and 85 patients with $\mathrm{HCV} /$ HIV coinfection. Table 1 summarizes the demographic and clinical characteristics of the patients. There were no significant differences in the baseline characteristics between each group in terms of mean age, BMI, mean ALT level, and the distribution of HCV genotypes and ss469415590 genotypes. There was a higher proportion of females among the HCV monoinfected patients in comparison to the HCV/HIV coinfected patients ( $\mathrm{p}<$ 0.001 ). In contrast, HCV/HIV coinfected patients had significantly higher mean liver stiffness, $\log _{10} \mathrm{HCV}$ RNA and $\log _{10} \mathrm{HCV} c \mathrm{Ag}$ levels compared with $\mathrm{HCV}$ monoinfected patients $(\mathrm{p}=0.004,0.018$ and 0.035, respectively).

\section{Correlation between $\log _{10} \mathrm{HCVcAg}$ and $\log _{10} \mathrm{HCV}$ RNA Levels}

In this study, serum HCV RNA and HCVcAg levels were detected in all cases. Mean $\log _{10} \mathrm{HCV}$ RNA was $6.1 \pm 1.0 \mathrm{IU} / \mathrm{ml}$ (range: $3.4-7.9 \mathrm{IU} / \mathrm{ml}$ ) and mean $\log _{10}$ $\mathrm{HCV}$ Ag was $3.6 \pm 0.6 \mathrm{fmol} / \mathrm{l}$ (range: $1.9-4.6 \mathrm{fmol} / \mathrm{l}$ ). In the overall cohort, $\log _{10} \mathrm{HCV}$ cAg levels significantly correlated with corresponding $\log _{10}$ HCV RNA levels ( $r=$ $0.889, \mathrm{p}<0.001$ ) as shown in figure 1 . Regarding HIV status, there were significant correlations between both markers in monoinfected patients $(\mathrm{r}=0.845, \mathrm{p}<0.001)$ and in coinfected patients $(\mathrm{r}=0.939, \mathrm{p}<0.001)$. However, the mean $\log _{10} \mathrm{HCV} \mathrm{RNA} / \mathrm{HCV} \mathrm{Ag}$ ratio was not sig-

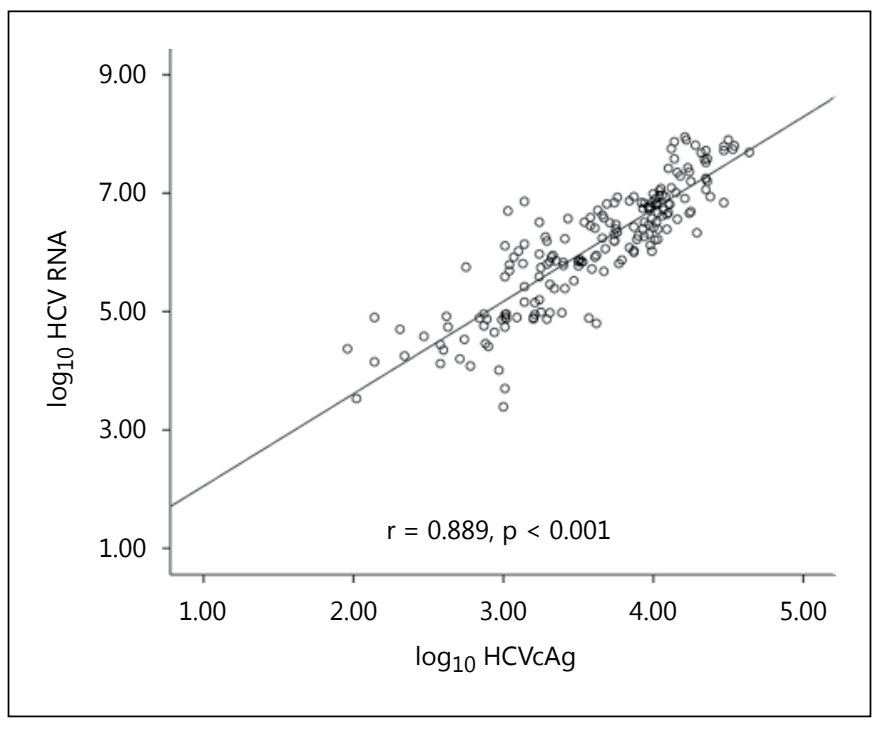

Fig. 1. Correlation between $\log _{10} \mathrm{HCV} c A g$ and $\log _{10} \mathrm{HCV}$ RNA levels in all patients.

Table 1. Demographics and characteristics of HCV-mono- and -coinfected patients

\begin{tabular}{|c|c|c|c|}
\hline Characteristics & $\begin{array}{l}\text { Monoinfection } \\
(\mathrm{n}=104)\end{array}$ & $\begin{array}{l}\text { Coinfection } \\
(\mathrm{n}=85)\end{array}$ & $\mathrm{p}$ \\
\hline Age, years & $45.6 \pm 9.7$ & $44.1 \pm 7.2$ & n.s. \\
\hline \multicolumn{4}{|l|}{ Sex } \\
\hline Males & $61(58.7)$ & $74(87.1)$ & \\
\hline Females & $43(41.3)$ & $11(12.9)$ & $<0.001$ \\
\hline $\mathrm{BMI}, \mathrm{kg} / \mathrm{m}^{2}$ & $23.9 \pm 4.2$ & $22.6 \pm 6.5$ & n.s. \\
\hline ALT, U/l & $74.3 \pm 55.6$ & $88.8 \pm 53.1$ & n.s. \\
\hline Liver stiffness, $\mathrm{kPa}$ & $9.1 \pm 5.6$ & $14.1 \pm 12.0$ & 0.004 \\
\hline $\mathrm{CD} 4+\mathrm{T}$ cell counts, cell $/ \mu \mathrm{l}$ & $441.4 \pm 216.6$ & & \\
\hline HCV RNA, $\log _{10} \mathrm{IU} / \mathrm{ml}$ & $6.0 \pm 1.0$ & $6.3 \pm 1.0$ & 0.018 \\
\hline $\mathrm{HCV} c \mathrm{Ag}, \log _{10} \mathrm{fmol} / \mathrm{l}$ & $3.5 \pm 0.6$ & $3.7 \pm 0.5$ & 0.035 \\
\hline \multicolumn{4}{|l|}{ HCV genotypes } \\
\hline 1 & $38(36.5)$ & $29(34.1)$ & \\
\hline 3 & $41(39.4)$ & $44(51.8)$ & \\
\hline 6 & $25(24.1)$ & $12(14.1)$ & n.s. \\
\hline \multicolumn{4}{|l|}{ IFNL4 genotypes } \\
\hline TT/TT & $92(88.5)$ & $74(87.1)$ & \\
\hline $\mathrm{TT} / \Delta \mathrm{G}$ & $7(6.7)$ & $10(11.8)$ & \\
\hline$\Delta \mathrm{G} / \Delta \mathrm{G}$ & $5(4.8)$ & $1(1.1)$ & n.s. \\
\hline
\end{tabular}

Data are presented as means $\pm \mathrm{SD}$ or $\mathrm{n}(\%)$. ALT $=$ Alanine aminotransferase.

nificantly different between monoinfected and coinfected patients $(1.69 \pm 0.18$ vs. $1.70 \pm 0.12$, respectively, $\mathrm{p}=$ 0.774).

Additionally, we investigated the correlation between both markers in terms of HCV viremia. Overall, high viral 
Table 2. Serum levels of $\log _{10}$ HCV RNA and $\log _{10}$ HCVcAg according to $\mathrm{HCV}$ genotypes

\begin{tabular}{lllll}
\hline & $\begin{array}{l}\text { Genotype 1 } \\
(\mathrm{n}=67)\end{array}$ & $\begin{array}{l}\text { Genotype 3 } \\
(\mathrm{n}=85)\end{array}$ & $\begin{array}{l}\text { Genotype 6 } \\
(\mathrm{n}=37)\end{array}$ & $\mathrm{p}$ \\
\hline $\begin{array}{c}\mathrm{HCV} \mathrm{RNA}, \log _{10} \\
\quad \mathrm{IU} / \mathrm{ml}\end{array}$ & $6.0 \pm 0.9$ & $6.1 \pm 1.0$ & $6.4 \pm 1.1$ & 0.227 \\
$\begin{array}{c}\mathrm{HCV} \text { cAg, } \log _{10} \\
\mathrm{fmol} / \mathrm{l}\end{array}$ & $3.5 \pm 0.5$ & $3.6 \pm 0.6$ & $3.8 \pm 0.6$ & 0.058 \\
\hline
\end{tabular}

load samples ( $\log _{10}$ HCV RNA $\left.\geq 5.0 \mathrm{IU} / \mathrm{ml}\right)$ showed a better correlation $(\mathrm{r}=0.815, \mathrm{p}<0.001)$ than low viral load samples $\left(\log _{10} \mathrm{HCV}\right.$ RNA $<5.0 \mathrm{IU} / \mathrm{ml}(\mathrm{r}=0.555, \mathrm{p}<$ 0.001 ). The same trends were also observed in the monoinfected group $(r=0.731, p<0.001$ and $r=0.462, p=0.015$, respectively) and the coinfected group $(\mathrm{r}=0.902, \mathrm{p}<$ 0.001 and $r=0.724, p=0.003$, respectively). Regardless of HIV status, mean $\log _{10} \mathrm{HCV}$ RNA/HCVcAg ratio was significantly higher in the high viral load group compared with the low viral load group $(1.72 \pm 0.13$ vs. $1.63 \pm 0.23$, respectively, $\mathrm{p}=0.002$ ).

\section{Correlation between $\log _{10} \mathrm{HCV}$ cAg Levels and $\mathrm{HCV}$} Genotypes

The correlation between $\log _{10} \mathrm{HCVcAg}$ and $\log _{10}$ HCV RNA levels was also evaluated with respect to $\mathrm{HCV}$ genotypes. Our data showed that $\log _{10} \mathrm{HCV} \mathrm{CAg}$ levels significantly correlated with $\log _{10} \mathrm{HCV}$ RNA across HCV genotypes with the best correlation found in HCV-3 [HCV-1 $(\mathrm{r}=0.796, \mathrm{p}<0.001), \mathrm{HCV}-3(\mathrm{r}=$ 0.919, $\mathrm{p}<0.001)$ and HCV-6 $(\mathrm{r}=0.895, \mathrm{p}<0.001)]$. When comparing the levels of $\log _{10} \mathrm{HCV}$ RNA and $\log _{10} \mathrm{HCV}$ cAg among different HCV genotypes, we did not observe any significant differences although patients with HCV-6 had slightly higher levels of both markers than the other groups (table 2). In addition, the levels of both markers regarding HIV status were not significantly different across HCV genotypes (data not shown).

The relationship between HCV genotypes and clinical parameters was further examined. Patients with HCV-3 infection had significantly higher mean ALT levels than patients with HCV -6 infection ( $90.8 \pm 53.6$ vs. $60.0 \pm 50.2$ $\mathrm{U} / \mathrm{l}$, respectively, $\mathrm{p}=0.004$ ), but did not significantly differ from patients with HCV-1 infection $(79.8 \pm 56.1 \mathrm{U} / \mathrm{l}$, $\mathrm{p}=0.229)$. There was no significant difference in liver stiffness among patients infected with $\mathrm{HCV}-1, \mathrm{HCV}-3$ and HCV-6.
Table 3. Serum levels of $\log _{10}$ HCV RNA and $\log _{10}$ HCVcAg according to ss469415590 genotypes

\begin{tabular}{llll}
\hline & $\begin{array}{l}\text { TT/TT genotype } \\
(\mathrm{n}=166)\end{array}$ & $\begin{array}{l}\text { Non-TT/TT genotype } \mathrm{p} \\
(\mathrm{n}=23)\end{array}$ \\
\hline $\begin{array}{l}\mathrm{HCV} \mathrm{RNA}, \log _{10} \\
\begin{array}{l}\mathrm{IU} / \mathrm{ml} \\
\mathrm{HCV} \mathrm{cAg}, \log _{10} \\
\mathrm{fmol} / \mathrm{l}\end{array}\end{array}$ & $6.2 \pm 1.0$ & $5.6 \pm 1.0$ & 0.014 \\
\hline
\end{tabular}

\section{Correlation between $\log _{10} \mathrm{HCVcAg}$ Levels and ss469415590 Genotypes}

Since a relatively small proportion of individuals displayed TT/ $\Delta \mathrm{G}$ or $\Delta \mathrm{G} / \Delta \mathrm{G}$ genotypes of ss 469415590 , we grouped these genotypes together for statistical analysis. As shown in table 3, patients harboring a TT/TT genotype had significantly higher levels of $\log _{10}$ HCV RNA than those with a non-TT/TT genotype ( $6.2 \pm 1.0$ vs. $5.6 \pm 1.0$ $\mathrm{IU} / \mathrm{ml}$, respectively, $\mathrm{p}=0.014)$. A similar observation was found for $\log _{10} \mathrm{HCV}$ cAg levels $(3.6 \pm 0.6$ vs. $3.3 \pm 0.5$ $\mathrm{fmol} / \mathrm{l}$, respectively, $\mathrm{p}=0.004)$.

In the monoinfected group, there was no significant difference between patients with TT/TT and non-TT/TT genotypes in terms of $\log _{10}$ HCV RNA ( $6.0 \pm 0.9$ vs. $5.4 \pm$ $1.2 \mathrm{U} / \mathrm{l}$, respectively, $\mathrm{p}=0.119)$ and $\log _{10} \mathrm{HCV}$ cAg levels ( $3.6 \pm 0.6$ vs. $3.3 \pm 0.6 \mathrm{fmol} / \mathrm{l}$, respectively, $\mathrm{p}=0.193$ ), although a trend towards increases in both markers were observed among the TT/TT genotype. In the coinfected group, patients harboring the TT/TT genotype had significantly higher levels of $\log _{10}$ HCV RNA and $\log _{10}$ HCVcAg than those with the non-TT/TT genotype (6.4 \pm 1.0 vs. $5.8 \pm 0.8 \mathrm{U} / \mathrm{l}$, respectively, $\mathrm{p}=0.034$, and $3.8 \pm 0.5$ vs. $3.3 \pm 0.3 \mathrm{fmol} / \mathrm{l}$, respectively, $\mathrm{p}=0.002$ ).

The relationship between the ss 469415590 genotypes and clinical parameters was also explored. Regarding baseline serum ALT level, there was no significant difference between patients with TT/TT and non-TT/TT genotypes $(83.8 \pm 56.1$ vs. $60.7 \pm 40.2 \mathrm{U} / \mathrm{l}$, respectively, $\mathrm{p}=$ 0.058 ), although a trend towards increased ALT levels was observed among the TT/TT genotype group. Similarly, there was no significant difference in liver stiffness between patients with TT/TT and non-TT/TT genotypes $(11.9 \pm 10.1$ vs. $13.9 \pm 11.2 \mathrm{kPa}$, respectively, $\mathrm{p}=0.543)$.

\section{Correlation between HCVcAg Levels and Clinical Parameters}

In addition to associations with $\mathrm{HCV}$ genotypes and ss469415590 genotypes, the relationship between
Duy Thong et al. 
HCVcAg levels and clinical parameters was examined. In this study, $\log _{10} \mathrm{HCV}$ cAg levels were not correlated with serum ALT levels $(r=-0.045, p=0.542)$ and liver stiffness $(\mathrm{r}=-0.122, \mathrm{p}=0.155)$. Similarly, $\log _{10}$ HCV RNA levels were not correlated with serum ALT $(\mathrm{r}=-0.031, \mathrm{p}=$ $0.676)$ and liver stiffness $(r=-0.078, p=0.365)$. We also analyzed the correlation between $\mathrm{HCV}$ Ag levels and $\mathrm{CD} 4+\mathrm{T}$ cell counts in the coinfection group. In this study, $\log _{10} \mathrm{HCV}$ Ag levels were not correlated with CD4+ T cell counts $(r=0.093, p=0.396)$. Similarly, $\log _{10} \mathrm{HCV}$ RNA levels were not correlated with $\mathrm{CD} 4+\mathrm{T}$ cell counts $(\mathrm{r}=0.063, \mathrm{p}=0.569)$.

\section{Discussion}

Detection of HCVcAg levels in the serum has emerged as a potential marker for active $\mathrm{HCV}$ infection and may be used to evaluate response to antiviral therapy and disease progression. Several recent data have demonstrated that serum $\mathrm{HCV} c A g$ concentrations correlate well with $\mathrm{HCV}$ RNA levels in HCV monoinfected patients [6-12]. In the present study, we further investigated the use of $\mathrm{HCV}$ cAg measurement in HCV/HIV coinfected patients. In particular, we directly compared the use of HCVcAg measurement between HCV monoinfected and HCV/HIV coinfected individuals, with respect to HCV genotypes, host genetic variations and other disease parameters that could influence the clinical outcome of chronic HCV infection.

Previous studies estimated that the sensitivity of the ARCHITECT HCVcAg assay is approximately $3 \mathrm{fmol} / \mathrm{l}$, which corresponds to $500-2,500 \mathrm{IU} / \mathrm{ml}$ of HCV RNA [7, $8,12]$. Thus, the concordance of detectable HCV RNA and HCVcAg of all samples in this cohort likely resulted from high viremia, which is a typical feature of untreated individuals. Our data confirmed previous reports that HCVcAg levels had a good correlation with the corresponding HCV RNA levels in both the mono- and coinfection groups. It should be noted that the correlation between both assays appeared to be higher among the coinfected group than the monoinfected group $(r=0.939$ and $r=0.845$, respectively). Indeed, the correlation coefficients between the two markers in coinfected patients exceeded 0.90 in most previous studies [15-17]. For example, a recent cross-sectional survey conducted in China demonstrated that the correlation coefficients between HCVcAg and HCV RNA concentrations was higher in coinfected than monoinfected subjects $(\mathrm{r}=0.952$ and $\mathrm{r}=$ 0.808 , respectively) [17]. Another study conducted in Germany showed that the correlation coefficients be-

Correlation between $\mathrm{HCV} c \mathrm{Ag}$ and $\mathrm{HCV}$ RNA Levels tween these two markers in HCV/HIV coinfection was 0.97 compared to 0.75 in HCV monoinfection [16].

It should be mentioned that the correlation between HCVcAg and HCV RNA levels was also typically high among other groups of patients with impaired immune response, including liver and kidney transplant recipients [27] and patients with end-stage kidney disease [28]. In contrast, such correlation was less consistent among immunocompetent individuals. Thus, it appears that the correlation between both markers of $\mathrm{HCV}$ replication might be in part influenced by the immune status of infected individuals. The explanation of these interesting findings are unclear, but might be related to an interaction between $\mathrm{HCV} c \mathrm{Ag}$ and anti-HCV antibodies. In general, it was proposed that anti-HCV antibodies might mask the detection of HCVcAg or could lead to an enhanced clearance of circulating antigen. However, among patients with impaired immune response including HIVinfected individuals or patients receiving immunosuppressive therapy, lower antibody levels presumably do not interfere with the measurement of HCVcAg $[16,27]$. In contrast, patients with $\mathrm{HBV} / \mathrm{HCV}$ coinfection did not show good correlation between the two markers [16], which might result from the complexity of viral interaction and fluctuation of virological dominance over time [29]. Collectively, these data indicate that HCVcAg measurement is an excellent surrogate marker for monitoring $\mathrm{HCV}$ viral replication in $\mathrm{HCV} / \mathrm{HIV}$ coinfected patients.

Of note, mean serum concentrations of HCV RNA and $\mathrm{HCV}$ cAg in our study were significantly higher in coinfected than monoinfected groups. These results are consistent with previous reports that $\mathrm{HCV} / \mathrm{HIV}$ coinfection is associated with persistent $\mathrm{HCV}$ viremia and higher $\mathrm{HCV}$ viral load [30]. The increased HCV RNA levels among coinfected patients are thought to be in part associated with the decline in $\mathrm{CD} 4+$ and $\mathrm{CD} 8+\mathrm{T}$ cell responses to $\mathrm{HCV}$ infection. Our data also showed that coinfected patients had significantly higher liver stiffness, representing more advanced liver fibrosis compared to monoinfected patients. These findings are in agreement with previous studies that the prevalence of significant liver fibrosis is usually high among coinfected individuals [31]. In the context of HCV/HIV coinfection, emerging data have suggested that multiple conditions, including increases in profibrogenic cytokine expression and secretion, enhancement of oxidative stress production, and increases in hepatocyte apoptosis all contribute to accelerated fibrosis [32]. In contrast to previous studies, our results did not demonstrate the correlation between $\mathrm{HCV} c \mathrm{Ag}$ concentration and liver inflammatory activity and liver fibrosis [33]. 
Unlike previous reports of $\mathrm{HCV} c \mathrm{Ag}$, our study included a proportion of patients infected with HCV-6. As mentioned previously, the data on this $\mathrm{HCV}$ genotype are sparse due to its restricted distribution in South China and Southeast Asia [18]. In this study, we observed slightly different correlations between HCVcAg and HCV RNA levels across $\mathrm{HCV}$ genotypes with the best correlations found in HCV-3, followed by HCV-6 and HCV-1, respectively. However, HCVcAg and HCV RNA levels did not vary according to HCV genotypes. Of note, samples with high viral load showed a better correlation of HCVcAg and HCV RNA concentrations than those with low viral load. In addition, the mean $\mathrm{HCV} \mathrm{RNA} / \mathrm{HCV} \mathrm{Ag}$ ratio was significantly higher among samples with high viremia compared to those with low viremia. These observations were presumably related to a higher proportion of unmasked $\mathrm{HCV}$ cAg detectable by the HCVcAg assay in the setting of high viremia, as described previously in $\mathrm{HCV} / \mathrm{HIV}$ coinfected patients and transplant recipients $[16,27]$.

Recent reports have shown that the $\Delta \mathrm{G}$ variant of ss469415590 is associated with poorer HCV clearance and response to antiviral therapy than the TT allele [22, 24]. However, the association of this polymorphism with $\mathrm{HCV}$ cAg levels remains to be elucidated. To our knowledge, our study is the first to assess IFNL4 genetic status in relation to $\mathrm{HCV} c \mathrm{Ag}$ levels in patients with chronic $\mathrm{HCV}$ infection. We found that patients harboring the TT/ TT genotype had significantly higher levels of HCV RNA and HCVcAg than those with the non-TT/TT genotype, regardless of HIV status and HCV genotypes. This finding is consistent with previous data in that the favorable CC genotype of rs12979860, which is associated with bet- ter treatment response, and is also related to higher baseline viral load $[19,34]$. The effects on HCV RNA and HCVcAg concentrations might be in part related to biological interaction between HCV replication and IFNL4 protein. As shown in previous studies, the IFNL4 $\Delta \mathrm{G}$ variant could induce weak expression of IFN-stimulated genes, which in turn provides an antiviral response in reducing $\mathrm{HCV}$ viral load. In contrast, the $\Delta \mathrm{G}$ variant also diminishes the responsiveness to type I and type III IFN required for effective treatment during antiviral therapy $[22,35]$. More information is needed to understand the mechanisms that underlie this association, as well as the clinical impact of ss 469415590 polymorphisms on $\mathrm{HCV}$ Ag detection.

In conclusion, our data showed that there was an excellent correlation between $\mathrm{HCV}$ RNA and $\mathrm{HCV} \mathrm{CAg}$ concentrations, particularly in HCV/HIV coinfected individuals. We also demonstrated that serum levels of HCVcAg were association with ss 469415590 polymorphism. As the HCVcAg assay is a reliable test and has the advantages of being rapid and reproducible, its measurement could be used as an alternative to HCV RNA assays in resource-limited settings.

\section{Acknowledgments}

This study was supported by the Research Unit of Hepatitis and Liver Cancer, the Center of Excellence in Clinical Virology, the Thailand Research Fund (BRG5580005, DPG5480002), and the Ratchadaphiseksomphot Endowment Fund of Chulalongkorn University (RES560530155). The authors would like to thank Sompong Vongpunsawad for editing the manuscript.

\section{References}

1 Mohd Hanafiah K, Groeger J, Flaxman AD, Wiersma ST: Global epidemiology of hepatitis $C$ virus infection: new estimates of age-specific antibody to HCV seroprevalence. Hepatology 2013;57:1333-1342.

-2 Akkarathamrongsin S, Praianantathavorn K Hacharoen N, Theamboonlers A, Tangkijvanich P, Tanaka Y, Mizokami M, Poovorawan Y: Geographic distribution of hepatitis C virus genotype 6 subtypes in Thailand. J Med Virol 2010;82:257-262.

3 Chevaliez S, Pawlotsky JM: Virology of hepatitis $C$ virus infection. Best Pract Res Clin Gastroenterol 2012;26:381-389.

4 de Leuw P, Sarrazin C, Zeuzem S: How to use virological tools for the optimal management of chronic hepatitis C. Liver Int 2011; 31(suppl 1):3-12.
5 Morota K, Fujinami R, Kinukawa H, Machida T, Ohno K, Saegusa H, Takeda K: A new sensitive and automated chemiluminescent microparticle immunoassay for quantitative determination of hepatitis $\mathrm{C}$ virus core antigen. J Virol Methods 2009; 157:8-14.

-6 Descamps V, Op de Beeck A, Plassart C, Brochot E, Francois C, Helle F, Adler M, Bourgeois N, Degre D, Duverlie G, Castelain S: Strong correlation between liver and serum levels of hepatitis $C$ virus core antigen and RNA in chronically infected patients. J Clin Microbiol 2012;50:465-468.

7 Kesli R, Polat H, Terzi Y, Kurtoglu MG, Uyar $\mathrm{Y}$ : Comparison of a newly developed automated and quantitative hepatitis $\mathrm{C}$ virus (HCV) core antigen test with the HCV RNA assay for clinical usefulness in confirming anti-HCV results. J Clin Microbiol 2011;49: 4089-4093.

-8 Medici MC, Furlini G, Rodella A, Fuertes A, Monachetti A, Calderaro A, Galli S, Terlenghi L, Olivares M, Bagnarelli P, Costantini A, De Conto F, Sainz M, Galli C, Manca N, Landini MP, Dettori G, Chezzi C: Hepatitis C virus core antigen: analytical performances, correlation with viremia and potential applications of a quantitative, automated immunoassay. J Clin Virol 2011;51:264-269.

>9 Murayama A, Sugiyama N, Watashi K, Masaki T, Suzuki R, Aizaki H, Mizuochi T, Wakita $\mathrm{T}$, Kato $\mathrm{T}$ : Japanese reference panel of blood specimens for evaluation of hepatitis $\mathrm{C}$ virus RNA and core antigen quantitative assays. J Clin Microbiol 2012;50:1943-1949. 
10 Ottiger C, Gygli N, Huber AR: Detection limit of architect hepatitis $\mathrm{C}$ core antigen assay in correlation with HCV RNA, and renewed confirmation algorithm for reactive antiHCV samples. J Clin Virol 2013;58:535-540.

11 Park Y, Lee JH, Kim BS, Kim do Y, Han KH, Kim HS: New automated hepatitis $C$ virus (HCV) core antigen assay as an alternative to real-time PCR for HCV RNA quantification. J Clin Microbiol 2010;48:2253-2256.

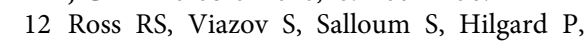
Gerken G, Roggendorf M: Analytical performance characteristics and clinical utility of a novel assay for total hepatitis $C$ virus core antigen quantification. J Clin Microbiol 2010; 48:1161-1168.

13 Dawson GJ: The potential role of HCV core antigen testing in diagnosing HCV infection. Antivir Ther 2012;17:1431-1435.

14 Kuo YH, Chang KC, Wang JH, Tsai PS, Hung $\mathrm{SF}$, Hung $\mathrm{CH}$, Chen $\mathrm{CH}$, Lu SN: Is hepatitis C virus core antigen an adequate marker for community screening? J Clin Microbiol 2012; 50:1989-1993.

15 Garbuglia AR, Monachetti A, Galli C, Sabatini R, Ferreri ML, Capobianchi MR, Bagnarelli P: HCV core antigen and HCV-RNA in $\mathrm{HIV} / \mathrm{HCV}$ co-infected patients with different HCV genotypes. BMC Infect Dis 2014; 14 : 222.

-16 Mederacke I, Potthoff A, Meyer-Olson D, Meier M, Raupach R, Manns MP, Wedemeyer H, Tillmann HL: HCV core antigen testing in HIV - and HBV-coinfected patients, and in HCV-infected patients on hemodialysis. J Clin Virol 2012;53:110-115.

$\checkmark 17$ Shen T, Chen X, Zhang W, Xi Y, Cao G, Zhi Y, Wang S, Xu C, Wei L, Lu F, Zhuang H: A higher correlation of HCV core antigen with CD4+ T cell counts compared with HCV RNA in HCV/HIV-1 coinfected patients. PLoS One 2011;6:e23550.

18 Thong VD, Akkarathamrongsin S, Poovorawan $\mathrm{K}$, Tangkijvanich $\mathrm{P}$, Poovorawan $\mathrm{Y}$ : Hepatitis $C$ virus genotype 6: virology, epidemiology, genetic variation and clinical implication. World J Gastroenterol 2014;20:29272940.

19 Ge D, Fellay J, Thompson AJ, Simon JS, Shianna KV, Urban TJ, Heinzen EL, Qiu P, Bertelsen AH, Muir AJ, Sulkowski M, McHutchison JG, Goldstein DB: Genetic variation in IL28B predicts hepatitis $C$ treatment-induced viral clearance. Nature 2009;461:399-401.
20 Suppiah V, Moldovan M, Ahlenstiel G, Berg T, Weltman M, Abate ML, Bassendine M, Spengler U, Dore GJ, Powell E, Riordan S, Sheridan D, Smedile A, Fragomeli V, Muller T, Bahlo M, Stewart GJ, Booth DR, George J: IL28B is associated with response to chronic hepatitis C interferon-alpha and ribavirin therapy. Nat Genet 2009;41:1100-1104.

21 Tanaka Y, Nishida N, Sugiyama M, Kurosaki M, Matsuura K, Sakamoto N, Nakagawa M, Korenaga M, Hino K, Hige S, Ito Y, Mita E, Tanaka E, Mochida S, Murawaki Y, Honda M, Sakai A, Hiasa Y, Nishiguchi S, Koike A, Sakaida I, Imamura M, Ito K, Yano K, Masaki N, Sugauchi F, Izumi N, Tokunaga K, Mizokami M: Genome-wide association of IL28B with response to pegylated interferon-alpha and ribavirin therapy for chronic hepatitis $\mathrm{C}$. Nat Genet 2009;41:1105-1109.

22 Prokunina-Olsson L, Muchmore B, Tang W, Pfeiffer RM, Park H, Dickensheets H, Hergott D, Porter-Gill P, Mumy A, Kohaar I, Chen S, Brand N, Tarway M, Liu L, Sheikh F, Astemborski J, Bonkovsky HL, Edlin BR, Howell CD, Morgan TR, Thomas DL, Rehermann B, Donnelly RP, O'Brien TR: A variant upstream of IFNL3 (IL28B) creating a new interferon gene IFNL4 is associated with impaired clearance of hepatitis C virus. Nat Genet 2013;45: 164-171.

23 Bibert S, Roger T, Calandra T, Bochud M, Cerny A, Semmo N, Duong FH, Gerlach T, Malinverni R, Moradpour D, Negro F, Mullhaupt B, Bochud PY: IL28B expression depends on a novel TT/-G polymorphism which improves HCV clearance prediction. J Exp Med 2013;210:1109-1116.

24 Stattermayer AF, Strassl R, Maieron A, Rutter K, Stauber R, Strasser M, Beinhardt S, Datz C, Scherzer TM, Steindl-Munda P, Gschwantler M, Trauner M, Hofer H, Ferenci P: Polymorphisms of interferon- $\lambda 4$ and IL28B - effects on treatment response to interferon/ribavirin in patients with chronic hepatitis C. Aliment Pharmacol Ther 2014;39:104-111.

25 Akkarathamrongsin S, Thong VD, Payungporn S, Poovorawan K, Prapunwattana $\mathrm{P}$, Poovorawan Y, Tangkijvanich P: IFNL3 (IL28B) and IFNL4 polymorphisms are associated with treatment response in Thai patients infected with HCV genotype 1, but not with genotypes 3 and 6. J Med Virol 2014;86: 1482-1490.

26 Castera L, Pinzani M, Bosch J: Non invasive evaluation of portal hypertension using transient elastography. J Hepatol 2012;56:696703.
27 Heidrich B, Pischke S, Helfritz FA, Mederacke I, Kirschner J, Schneider J, Raupach R, Jackel E, Barg-Hock H, Lehner F, Klempnauer J, von Hahn T, Cornberg M, Manns MP, Ciesek S, Wedemeyer $\mathrm{H}$ : Hepatitis $\mathrm{C}$ virus core antigen testing in liver and kidney transplant recipients. J Vir Hepat 2014;21:769-779.

-28 Li Cavoli G, Zagarrigo C, Schillaci O, Servillo F, Tralongo A, Coglitore M, Spadaro F, Scimeca C, Li Destri N, Rotolo U: Hepatitis C virus core antigen test in monitoring of dialysis patients. Hepat Res Treat 2012;2012: 832021.

29 Chu CJ, Lee SD: Hepatitis B virus/hepatitis C virus coinfection: epidemiology, clinical features, viral interactions and treatment. J Gastroenterol Hepatol 2008;23:512-520.

30 Hernandez MD, Sherman KE: HIV/hepatitis $\mathrm{C}$ coinfection natural history and disease progression. Curr Opin HIV AIDS 2011;6:478482.

31 Mohsen AH, Easterbrook PJ, Taylor C, Portmann B, Kulasegaram R, Murad S, Wiselka M, Norris S: Impact of human immunodeficiency virus (HIV) infection on the progression of liver fibrosis in hepatitis C virus infected patients. Gut 2003;52: 1035-1040.

32 Lin W, Weinberg EM, Chung RT: Pathogenesis of accelerated fibrosis in HIV/HCV coinfection. J Infect Dis 2013;207(suppl 1):S13S18.

33 Durante-Mangoni E, Vallefuoco L, Sorrentino R, Iossa D, Perna E, Molaro R, Braschi U, Zampino R, Sodano G, Adinolfi LE, Utili R, Portella G: Clinico-pathological significance of hepatitis $\mathrm{C}$ virus core antigen levels in chronic infection. J Med Virol 2013;85:19131918.

34 Uccellini L, Tseng FC, Monaco A, Shebl FM, Pfeiffer R, Dotrang M, Buckett D, Busch MP, Wang E, Edlin BR, Marincola FM, O'Brien TR: HCV RNA levels in a multiethnic cohort of injection drug users: human genetic, viral and demographic associations. Hepatology 2012;56:86-94.

35 Bibert $\mathrm{S}$, Roger T, Calandra T, Bochud M, Cerny A, Semmo N, Duong FH, Gerlach T, Malinverni R, Moradpour D, Negro F, Mullhaupt B, Bochud PY: Swiss Hepatitis C Cohort Study: IL28B expression depends on a novel TT/-G polymorphism which improves HCV clearance prediction. J Exp Med 2013; 210:1109-1116. 